\title{
LIBERALIZATION AND \\ DEMOCRATIZATION: THE FORUM AND THE HEARTH IN THE ERA OF COSMOPOLITAN POST-INDUSTRIAL CAPITALISM
}

\author{
SOL PICCIOTTO*
}

I

\section{INTRODUCTION}

THE MISNOMER OF PRIVATIZATION

The processes described under the misleading term "privatization" have been part of a major social restructuring in both the political and economic spheres. Most notably, widespread state failures have resulted in significant changes in the form and functions of the state. This reform encompasses not only the collapse of state socialism, but also crises and radical reforms in developed capitalist states, including U.S. regulated corporatism, European-style social-democratic welfare states, and the developmental states of Japan and the Asian "tigers." The causes of these changes have been equally diverse, involving a mixture of both political and economic factors. Nevertheless, these processes have much in common, entailing a transition to post-industrial capitalism, or what Manuel Castells has called the "Information Age."

The crisis of the state has been most evident in eastern Europe and the former Union of Soviet Socialist Republics, which experienced a systemic social crisis of both political autocracy and economic centralization. Elsewhere, the relationships between the political and economic aspects have been less explicit, and thus the overall nature of the processes has been harder to grasp. One linking element has been the increased difficulty of legitimizing public expenditures from general taxes-especially those paid by direct taxes on income. This problem applied not only to social and welfare spending, but also to public funding of the renewal of infrastructure, in particular, expenses to keep pace with emerging needs and technologies in areas such as transportation and telecommunications.

\footnotetext{
Copyright (c) 2001 by Sol Picciotto

This article is also available at http://www.law.duke.edu/journals/63LCPPicciotto.

* Professor of Law, Lancaster University.

1. See generally Manuel Castells, The Information Age: Economy, Society And Culture (1996).
} 
At the same time, political systems found it increasingly difficult to resolve conflicting claims and demands in public services. New mechanisms were devised to decentralize decisionmaking and introduce "market principles" into public sector resource allocation. Although these changes were often presented as a decentralization or devolution of power, this characterization was in many respects misleading because the power devolved was generally limited to micromanagement of shrinking resources within the parameters defined from above. I had first-hand experience of this process as an elected school governor from 1989 to 1991, not long after the British Conservative government had introduced devolved budgetary management in schools. That system was billed as a transfer of power from local education authorities to head-teachers and governors. In practice, it relieved our local authority of the responsibility for difficult decisions, such as deciding whether to close small rural schools or balancing staffing needs against book purchasing; however, central government essentially determined the parameters for these decisions by setting the weighting criteria for budgetary allocations to schools. Similar attempts were made in other public services, such as health care.

Thus, although there has been much political talk of "rolling back the state," the process has largely consisted of remodeling the "public" sphere of politics and its relationship to the "private" sphere of economic activity. This is shown even by crude measures, such as state expenditure as a proportion of Gross Domestic Product ("GDP"), which has scarcely fallen even in countries where there has been extensive privatization. ${ }^{2}$ At the same time, major transformations have also been occurring in the forms of organization of so-called private enterprise, that is, the business economy dominated by the giant corporation. Large-scale mass manufacturing has been reorganized, and the centralized bureaucratic firm has become the "lean and mean" corporation, concentrating on its "core competencies" but operating within a web of strategic alliances, supplier chains, and financial and governmental networks."

Many of these changes have been driven by social pressures from below. There have been widespread revolts against autocratic power in the family and the factory, the classroom and the boardroom. In general terms, these revolts entail a rejection of authoritarian domination and the power to control truth embodied in tradition, involving demands for increased personal freedom, dignity, equality (notably between women and men), and an end to coercion. ${ }^{4}$ Rather than the desire for economic liberalization bringing about political democratization, the struggles against autocracy have created an opening for eco-

2. See World Bank, World DeVelopment Report 1997: The State in a Changing WORLD 22 (1997).

3. Bennett Harrison, LeAn and Mean: The Changing Landscape of Corporate POWER IN THE AGE OF FLEXIBILITY (1994) (stressing that this transition has not been a matter of small firm dynamism, but a reorganization of big business adapting to an era of rapid technological change, shorter product life cycles, and specialized but globalized markets).

4. See generally ANTHONy GidDEns, RunAwAy WORLD: How Globalization is RESHAPING OUR LIVES (2000). 
nomic liberalization. ${ }^{5}$ While undermining patriarchy and hierarchy, these antiauthoritarian movements have also paved the way for post-industrial capitalism, with its emphasis on information management, flexible working conditions, and a global outlook.

These changes have undoubtedly been very liberating for those who, in many ways, constitute a new global elite, but the benefits have been limited, partial, and exclusionary. Certainly, most people in Western Europe and North America enjoy high living standards, and many in Asia and Latin America have felt the benefits of development. At the same time, an increased polarization has occurred both within and between states. The gap between rich and poor states has continued to widen, and income inequality has increased even in developed countries; marginalization, poverty, and social exclusion affect both the underclass in developed countries and wide regions of underdevelopment, especially in Africa. ${ }^{6}$ Also, many of those who have benefited materially have nevertheless experienced greater insecurity and alienation, and the disintegration of traditional social bonds has led to new assertions of identity-sometimes destructive ones-based on ethnic or cultural exclusivity.

\section{II}

\section{GLOBALIZATION AND REGULATION}

Privatization and liberalization have been part of a broader process now generally referred to as globalization. They have entailed the transfer of many sectors of economic activity out of state ownership, the dismantling of direct forms of state control, and the removal of barriers to market access both within and between states, greatly facilitating the potential for the flow of goods and capital. Although this transformation is often called deregulation, it has also been widely recognized that there has, in practice, been a growth of new forms of regulation, or re-regulation. ${ }^{7}$ Indeed, national regulatory reforms have often facilitated the globalization of markets, ${ }^{8}$ and the process of re-regulation has in many cases entailed a complex interaction between national and international,

5. Political studies have found that domestic factors have had the strongest influence in democratic transitions, although the international context plays an important part through processes of emulation and influence. See, e.g., THE InTERnATIONAL DiMENSIONS OF DEMOCRATIZATION: EUROPE AND THE AMERICAS (Laurence Whitehead ed., 1996) [hereinafter INTERNATIONAL DIMENSIONS]. However, as Philippe Schmitter indicates, the transmission belt for democratization has been the international communication outside government controls of images and ideas, rather than a simple causal link of economic freedom stimulating political democratization. See Philippe Schmitter, The Influence of the International Context upon the Choice of National Institutions and Policies in NeoDemocracies, in INTERNATIONAL DiMENSIONS, supra, at 26-56. Schmitter also points out that the hypothesis that economic freedom leads to political democracy is an inversion of Kant's assumption that republics would be more likely to engage in international commerce and renounce war. See IMMANUEl KANT, TOWARD PERPETUAL PEACE (1795) (cited in Schmitter supra).

6. See MAnuel Castells, The Information AgE: End OF Millennium 70-165 (1998).

7. See Deregulation or Re-Regulation: Regulatory ReForm in Europe AND the UNITED STATES (Giandomenico Majone ed., 1990).

8. See Alfred Aman, A Global Perspective on Current Regulatory Reform: Rejection, Relocation, or Reinvention?, 2 IND. J. GloBAL LEGAL STUD. 429, 429-64 (1995). 
as well as public and private sector, initiatives.' Although there is a continuing neo-liberal ideological and institutional momentum to remove all national barriers to market access for goods, services, and capital, there has been a greater emphasis since the mid-1990s on the phasing of liberalization and the need for it to be accompanied by improvements in national state regulation. ${ }^{10}$ Much less attention has been given to improving the institutions of global governance, ${ }^{11}$ which is at least of equal importance.

The question of remodeling the global public sphere is generally approached as a technical rather than a political matter. This is reflected in the use of the two key terms- "regulation" and "governance." The concept of regulation can be understood as the capacity of the social system to adapt and stabilize in response to politico-economic dynamics (as in the French "regulation school"); or more particularly, regulation may refer to explicit, legally formalized mechanisms for directing or supervising economic activities. In many ways it has been paralleled by the term "governance," which seems to have been introduced into the parlance of the so-called Washington consensus by World Bank officials, constrained by the World Bank's constitution from intervening in the domestic political affairs of states, who found it a useful euphemism in raising issues such as corruption. ${ }^{12}$ The term "governance" also reflected a technicist view of social management that had a wider resonance. Thus, among some theorists of political science and public administration, it has been used to analyze changing patterns of state-market coordination, which can be more decentralized and interactive, responding to social complexity and failures of government or political control. ${ }^{13}$

9. The best example is financial services. For further details, see Sol Picciotto \& Jason Haines, Regulating Global Financial Markets, 26 J.L. \& SOC'Y 351 (1999).

10. This movement was signaled by the World Bank. See WORLD BANK, supra note 2, at 75 (stressing the importance of reinvigorating state capacity, conceding that the shift in the 1980s to the minimalist state "overreached many states' institutional capabilities," and urging that "[e]very country must also look to build and adapt its institutions, not dismantle them"). This viewpoint was renewed following the Asian crises. See Joseph Stiglitz, More Instruments and Broader Goals: Moving Towards the Post-Washington Consensus, 1998 WIDER Lecture Before the U.N. University-World Institute for Development Economics Research, Helsinki (Jan. 7, 1998) (visited Oct. 4, 2000) <http://www.world bank.org/html/extdr/extme/js-010798/wider.htm>. For a discussion of this shift in relation to legal institutions, see Lawrence Tshuma, The Political Economy of the World Bank's Legal Framework for Development, 8 SOC. \& LEGAL STUD. 75 (1999); GOOD GOVERNMENT AND LAW: LEGAL AND INSTITUTIONAL REFORM IN DEVELOPING COUNTRIES (Julio Faundez ed., 1997).

11. This was addressed in the report of the Commission on Global Governance but has had relatively little resonance. See COMMISSION ON GLOBAL GOVERnANCE, OUR GLOBAL NEIGHBOURHOOD (1995).

12. See Yves Dezalay \& Bryant Garth, The Internationalization of Palace Wars (forthcoming 2001). The World Bank was also influenced to take greater account of the role of the state by the success of the East Asian "developmental states." See Robert Wade, Japan, The World Bank, and the Art of Paradigm Maintenance: The East Asian Miracle in Political Perspective, 217 NEW LEFT REV. 3, 3-36 (1996).

13. See Modern GovernanCE: NeW GOVERnMENT-SOCIETY INTERACTIONS (Jan Kooiman ed., 1993). Renate Mayntz, using a systems-theory perspective, traces the term back to German debates on "soziale Steuerung," when it was used as an equivalent for the Parsonian concept of control (as in control hierarchy); however, this meaning obscured the distinction between governing (the intentional application of measures to achieve goals) and governance (which recognizes that social subsys- 
The use of these terms is both descriptive and normative. They reflect real historical developments, with the transformation of large-scale industrial production and centralized planning systems (both state and corporate) leading to the emergence of more flexible and interactive modes of production and distribution based on electronic technologies, as well as major changes in money and finance involving new forms of market intermediation of savings and investment. At the same time, these concepts are often used to legitimize the increasingly important role of a variety of professionals operating in the increasingly large interface between the state-which has been substantially "privatized"-and the market-which is dominated by corporate networks. Not surprisingly, each group tends to give its own ideological spin to the terms: policy-makers and lawyers advocate deliberately designed governing mechanisms and formalized regulation, while economists emphasize the self-governing capacities of market-based systems. ${ }^{14}$

Thus, one important aspect of globalization has been the process of fragmentation of the public sphere, reflecting shifts in the character and relationships of private and public institutions and resulting in systems of layered governance based on regulation..$^{15}$ A number of writers have described this fragmentation in terms of the emergence of regulatory webs or networks, although they offer different analyses of the phenomenon and its implications differ in various ways. Susan Strange has analyzed the emergence of networks of power in the international political economy. ${ }^{16}$ Anne-Marie Slaughter refers to the "disaggregation" of the state, and the development of international regulatory cooperation through inter-governmental networks. ${ }^{17}$ John Braithwaite and Peter Drahos have conducted an impressive survey and analysis of the role of global regulatory webs in the globalization of business. ${ }^{18}$ Writers on the European Union increasingly conceptualize it in terms of transnational regulatory networks, ${ }^{19}$ and Manuel Castells describes the European Union as the Network

tems have autonomous capacities to develop and will react and adapt to governing measures). See Renate Mayntz, Governing Failures and the Problem of Governability: Some Comments on a Theoretical Paradigm, in MODERN GOVERNANCE, supra, at 9.

14. See generally Regulatory PoliCy AND the Social ScIEnCES (Roger G. Noll ed., 1985).

15. See generally ORGANISATION FOR ECON. COOP. AND DEV., REGULATORY CO-OPERATION FOR AN INTERDEPENDENT WORLD (1994) (visited Oct. 4, 2000) (Executive Summary available at $<\mathrm{http} / / /$ oecd.org/puma/regref/coopern.htm>); see also Sol Picciotto, Networks in International Economic Integration: Fragmented States and the Dilemmas of Neo-Liberalism, 17 NW. J. INT'L L. \& Bus. 1014 (1996-97).

16. See Susan Strange, Who Governs? Networks of Power in World Society, 1994 HiTOTSUBASHI J.L. \& POL. 5; see also SUSAN STRANGE, STATES AND MARKETS (2d ed. 1988).

17. See Anne-Marie Slaughter, The Real New World Order, 76 FOREIGN AFF., Sept.-Oct. 1997, at 183, 184, 195.

18. See John Braithwaite \& Peter Drahos, Global Business Regulation (2000).

19. See, e.g., Renaud Dehousse, Regulation by Networks in the European Community: The Role of European Agencies, 4 J. EUR. PUB. POL. 246, 246-61 (1997). Giandomenico Majone sees it as part of a more general phenomenon of delegation of public functions or powers to specialist and often technical bodies. See Regulating Europe: European Public Policy (Giandomenico Majone ed., 1996). 
State, while he asserts that networks are the prime characteristic of the emerging social structures of the "Information Age." 20

Some political and international relations theorists, who have identified the important role of these international regulatory networks, have put forward analyses theorizing them as an essentially technocratic infrastructure or a delegation of administrative powers. ${ }^{21}$ They consider that specialists or experts merely facilitate the normal channels of government and international relations by dealing with detailed and essentially technical tasks, thus making it easier for the traditional democratic government structures to resolve the more general and important political issues. Emanuel Adler and Peter Haas argued that the "epistemic communities" of experts sharing a common set of values can facilitate the resolution of global policy issues by "narrowing the range within which political bargains could be struck." 22 As an example, they cited the way in which the core of the Bretton Woods monetary system-fixed rates and the dollargold standard-was agreed to by expert consensus, leaving a narrower range of issues, such as the extent of balance-of-payments support, to be "resolved purely through political muscle." ${ }^{23}$ However, the insider memoirs of Raymond Mikesell give a very different and more plausible flavor of those negotiations, showing that the "experts" of that period (1943 to 1945) were highly political individuals such as Harry White, and that key matters, such as the proposed IMF quotas, were calculated on the basis of political acceptability, although put forward as objective and scientific in order to facilitate acceptance. ${ }^{24}$

These propositions suggest that the growth of international regulatory or governance networks does not constitute the reduction of the scope of interstate politics, but rather its pursuit by other means. ${ }^{25}$ Certainly, it may entail an attempt to "depoliticize" issues, by deploying scientific, managerial, or professional techniques and basing their solution on universalizing discourses. However, such techniques are neither neutral in themselves, nor in the processes of their development and application. To operate effectively, they must interact with intersecting epistemologies within a process that can also reflect wider public concerns, to produce socially acceptable value judgments. That specific technical issues cannot easily be isolated from wider cultural, social, and political factors is borne out by the frequently divergent views and disagreements on decisions between experts or specialists from different national and cultural

20. For a discussion of networks, see MANUEL CASTELls, THE INFORMATION AGE: THE Rise OF THE NETWORK SOCIETY (1996) [hereinafter CASTELls, NETWORK SOCIETY]; for Europe, see CASTELLS, MiLLENNIUM, supra note 6.

21. See generally REGULATING EUROPE, supra note 19; Slaughter, supra note 17.

22. Emanuel Adler \& Peter M. Haas, Conclusion: Epistemic Communities, World Order, and the Creation of a Reflective Research Programme, 46 INT'L ORG. 367, 378 (1992).

23. $I d$.

24. See generally RAymond Frech Mikesell, The Bretton Woods Debates: A Memoir (1994).

25. See Yves Dezalay, Between the State, Law and the Market: The Social and Professional Stakes in the Construction and Definition of a Regulatory Arena, in INTERNATIONAL REGULATORY COMPETITION AND COORDINATION 59 (William Bratton et al. eds., 1996). 
backgrounds. While international bureaucracies still prefer to represent their role as a technocratic one, they apparently have begun to accept-perhaps in response to criticism - that it has a political dimension, at least in terms of the concern that their policies should be acceptable to the public. ${ }^{26}$

Thus, while there is an important role for specialist expertise in regulatory decisionmaking, it is important that it should be exercised within a framework that is accountable and responsive. This includes direct democratic accountability because the powers of regulators have important social effects-even if they are narrow in scope. For example, central bankers set short-term interest rates, utility regulators have power over pricing or service obligations, and scientists set the allowable catch from a fishery. Much of the discussion of regulation starts from the mistaken assumption that it is an external imposition on markets, only justified in cases of market failure, and limited to market facilitation rather than redistribution. ${ }^{27}$ These assumptions underpin the view that market-facilitative regulation can and should be guided purely by efficiency considerations and can therefore be done technocratically, because only decisions involving redistribution (or the allocation of scarce resources) entail social value judgments and thus political legitimization. In fact, a market economy cannot exist without norms of many kinds, from technical standards to semiformal regulation to formal legal rules. These are the norms that create and define property rights, the institutions and structures of production and distribution, and the conditions of competition. ${ }^{28}$ They therefore have a major impact on livelihoods and health and living standards, and their legitimacy depends on wide social acceptability. The importance and complexity of such forms of regulation has increased in post-industrial, globalized capitalism, which has led to pressure for new forms of democratization of the accountability of formal regulatory rule-making even at the national level. This regulation is not a merely technical matter, but must be done as a process of open interaction with a wide public, subject to checks on the exercise of private influence.

Thus, the fragmentation of the public sphere and the emergence of new patterns of governance entail a rethinking of accountability or legitimacy. In this perspective, the problem of globalization does not simply result from disjunctures between nationally organized political systems and increasingly globally oriented economic activity or even power structures. It stems, rather, from changes in the form and functions of the state itself, as well as its international structures, resulting from the dynamic of socio-economic relations. What globalization means, and the shape it might take, are as much political as economic

26. See, e.g., Christine Landfried, Beyond Technocratic Governance: The Case of Biotechnology, EUR. L.J. 255 (1997) (discussing the European Commission). For a discussion of the changes in methods of operation of global economic institutions in response to political pressures, see Robert O'Brien, NGOs, Global Civil Society, and Global Economic Regulation, in REGUlATING INTERNATIONAL Business: BEYOND LiberalizATION 257 (Sol Picciotto \& Ruth Mayne eds., 1999).

27. See generally STEPHEN BREYER, REGULATION AND ITS REFORM 15-35 (1982).

28. See generally David Campbell \& Sol Picciotto, Exploring the Interaction between Law and Economics: The Limits of Formalism, 18 LEGAL STUD. 249 (1998). 
questions. A new global public sphere has been under construction for some time, but it has come from the policies and decisions of international elites. The question now is whether and how it can be democratized.

\section{III}

\section{Global GOVERnANCE: NEO-KANTIAN MODELS}

The challenge is to find new democratic forms that match the new, globally integrated patterns of production and consumption. While there is much talk of the "democratic deficit" of regional and international institutions, debate about how it might be remedied is at best half-hearted, or even skeptical. ${ }^{29}$ This skepticism can be readily understood if we continue to think in terms of a simple electoral representative model of democracy. No one seriously envisages the possibility of a global government on this model, and indeed, the greater awareness of the importance of locality and diversity resulting from economic globalization renders it even less believable.

This dilemma can be seen in much of the discussion of the prospects and proposals for "cosmopolitan democracy." This debate recognizes that globalization, based on the neo-liberal vision of the removal of barriers and the unleashing of the forces of economic self-interest, is at best unstable if it cannot deliver social justice. Global social justice issues, moreover, must be debated and resolved within a global public sphere. ${ }^{30}$ However, there is too little understanding or analysis of the nature of this global public sphere. It is frequently said to entail the emergence of some sort of global or international civil society. Yet there is considerable vagueness about who are the members of such a global civil society; in the perspective of international relations, they are seen in an undifferentiated way as non-state actors, as opposed to states (meaning governments), which are the traditional members of international society. Certainly, the more sophisticated theorists concede that "the spatial reach of the modern nation-state did not fix impermeable borders for other networks" and that "political communities have rarely-if ever-existed in isolation as bounded geographical totalities, and they are better conceptualized as overlapping networks of interaction." ${ }^{31}$ Indeed, one can go further and point out that territorially defined states themselves have always formed overlapping and interlocking spheres, as the exercise of state powers was mediated through the flexible concept of jurisdiction. Thus, the classical liberal international state system of Immanuel Kant and Adam Smith was already composed of interde-

29. Robert A. Dahl argues that international organizations are, and can only be, bureaucratic bargaining systems among elites. This conclusion flows from his view that the problem of delegation, already great for national representative systems, becomes insuperable for international politics. See Robert A. Dahl, Can International Organizations be Democratic? A Skeptic's View, in DEMOCRACY's EDGES 19 (Ian Shapiro \& Casiano Hacker-Cordon eds., 1999).

30. See generally Richard Devetak \& Richard Higgott, Justice Unbound? Globalization, States and the Transformation of the Social Bond, 75 INT'L AFF. 483, 483-98 (1999).

31. David Held, Democracy and the Global Order: From the Modern State to COSMOPOLITAN GOVERNANCE 225 (1995). 
pendent states, and the growth of corporate industrial capitalism has, since the second half of the nineteenth century, depended on international arrangements, many of which (such as the system of intellectual property) resulted from the debates and pressures of "international civil society." "32

Those who seek a foundation of legitimacy for global economic liberalization tend simply to resort to prescriptions for universal rights and principles of justice. ${ }^{33}$ This entails no revision of the dominant existing model of representative democracy based on the nation-state but seeks to ensure its adoption in all states, which should be bound together within a strong framework of international law and institutions embodying individual human rights. In this perspective "equal rights of the citizens may offer the most effective strategy for compensating the 'democratic deficit' of international organizations." ${ }^{34}$ This would actualize Kant's vision of "Perpetual Peace," based on a confederation or league of republican states, which would renounce war and pursue reciprocal economic benefits through trade, under an umbrella of principles embodying individual cosmopolitan rights. ${ }^{35}$

This ultra-liberal view assumes that the pursuit of individual self-interest, especially through economic exchange, is ultimately beneficial to all, so that the development of principles embodying individual rights, and the adjudication of conflicting rights-claims, would be sufficient to ensure universal consent and legitimacy. This would therefore justify even the entrenchment of internationally agreed principles so as to override national parliamentary supremacy, to secure the "effective judicial protection of the transnational exercise of individual rights." Many, even lawyers, will be skeptical of the faith this places in general liberal principles of law. Democracy is far more than the rule of law, which can at best provide a framework for adjudicating competing claims of right. Political processes must decide who should have what rights. This was seen, for example, in the debates around the proposed Multilateral Agreement on Investment ("MAI"), which was criticized on the grounds that it would grant strongly enforceable rights for corporations and investors without any concomitant responsibilities and impose disciplines on states without strengthening state regulatory capacity. ${ }^{37}$

Others have put forward somewhat modified, neo-Kantian models, which accept the need for a strengthening of the international institutional framework to provide an underpinning for "cosmopolitan democratic public law." But

32. For a more detailed analysis, see CRAIG N. MURPHY, INTERNATIONAL ORGANIZATION AND Industrial Change: Global Governance Since 1850 (1994); Sol Picciotto, The Regulatory Criss-Cross: Interaction between Jurisdictions and the Construction of Global Regulatory Networks, in INTERNATIONAL REGULATORY COMPETITION AND COORDINATION, supra note 25, at 89.

33. See Ernst-Ulrich Petersmann, How to Constitutionalize International Law and Foreign Policy for the Benefit of Civil Society?, 20 MICH. J. INT'L L. 1, 28 (1998).

34. Id.

35. See generally KANT, supra note 5 .

36. Petersmann, supra note 33 , at 26.

37. See generally REGULATING INTERNATIONAL BUSINESS, supra note 26. 
what seems to be envisaged does not appear very different from what I have described as the ultra-liberal model, somewhat reinforced by improving the representativeness of regional and international organizations. ${ }^{38}$ There are clear contradictions and limits to the neo-Kantian models. ${ }^{39}$ A new approach should begin by more adequately taking into account the ways in which the new forms of global socio-economic integration, the changed nature of the state, and the fragmentation of the public sphere entail new modes of accountability - and hence new democratic forms - at all levels.

Essentially, without a democratization of the global public sphere, a radical liberal vision of cosmopolitan citizenship and universal individual rights lacks any substantial democratic content.

IV

\section{DIRECT DELIBERATIVE DEMOCRACY}

The discussion of the limits of neo-Kantian models for democratizing globalism points to the need for new concepts and forms of democratic accountability that are responsive to the fragmentation of the public sphere and the more dispersed, decentralized, and multi-layered forms of regulating the exercise of social power. Indeed, this process of fragmentation results from the limits and contradictions of previous, state-centralized forms and also stimulates new forms of legitimation. The very decentralization of decisionmaking provides opportunities for accountability, because power is less concentrated. To that extent, it is accurate to see a connection between liberalization and increased liberty, and even accountability. The dispersal of decisionmakers provides automatic checks and balances, because a decision by one committee or regulator is rarely definitive. The much greater opportunities for strategic behavior and regulatory arbitrage generate regulatory competition. Decentralization has the potential for ratcheting standards up, as well as down. Although this tends to favor those with greater opportunities for mobility, and to destabilize and thus downgrade existing, socially-embedded regulatory arrangements and capacities, it also opens up prospects for strategic actions by new types of citizen groups and social organizations. ${ }^{40}$ This effect helps to explain the mushrooming growth of issue-oriented social movements broadly described as NonGovernmental Organizations ("NGOs").

38. This appears to be the argument of David Held. See HELD, supra note 31, at 255; see also David Held, Cosmopolitan Democracy and the Global Order: A New Agenda, in PeRPetual Peace 235, 235-51 (James Bohman \& Mathias Lutz-Bachman eds., 1997).

39. These are explored by the contributors to PERPETUAL PEACE, supra note 38, although they are generally concerned for various reasons to rescue what can be salvaged rather than to look for a new approach. As the editors of the collection point out in their introduction, "Escaping the dilemmas of despotism and fragmentation remains the most difficult institutional challenge of a cosmopolitan order; showing how the public use of reason permits both unity and difference is a task that the Kantian conception of reason has yet to solve." Id. at 18 .

40. For a detailed analysis with many examples and practical suggestions, see BRAITHWAITE \& DRAHOS, supra note 18. 
However, the constitution of democracy requires the formulation of principles adapted to the emerging forms of the new public sphere, but which explicitly aim to structure that democracy to ensure the most effective forms of popular participation. The dangers of liberalization and globalization are that they unleash socially destructive behavior based on the competitive pursuit of self-interest, as existing normative and institutional restraints are undermined or dismantled. Who can genuinely be surprised when full-blooded liberalization results in widespread corruption and the rapid growth of organized crime, as has occurred, for example, in Russia ${ }^{41}$

Thus, new democratic constitutional principles should foster active deliberation by citizens, based on the articulation and evaluation of generally applicable values in a variety of public forums and institutions. The most helpful and relevant approaches emerge from the work of political theorists arguing for new forms of direct democracy based on deliberative principles and aiming to contain or counterbalance instrumental rationality by fostering public debate and decisionmaking through communicative interaction and reasoning. ${ }^{42}$ They attempt to respond to the challenge posed to both liberal and republican (or communitarian) democracy by social fragmentation, which generates a politics of identity, often based on the view that differences are unassimilable. ${ }^{43}$

These proposals do not reject representative government; in fact they respond to the ways in which it has been transformed. Bernard Manin has comprehensively and convincingly analyzed these transformations, with the progressive breakdown of party democracy, in which parliaments became a register of the relative force of clashing interests that governments aimed to resolve by compromises. ${ }^{44} \mathrm{He}$ charts the rise of a new form of representation, in a context of greater complexity and unpredictability. He sees the electorate now as appearing "above all, as a public which responds to the terms that have been presented on the political stage," while politicians offer a choice among images which are "highly simplified and schematic political representations." ${ }^{45}$

Opinions on specific issues are no longer pre-formed or defined by group political identities and hence must be formulated and developed through debate in various public forums (although such debate is dominated by communications media that are less partisan, but more prone to drama and sensational71.

41. See Gregor Yavlinsky, Russia's Phony Capitalism, 77 ForeIGn AFF., May-June 1998, at 67, 68-

42. See generally JOHN S. DRYZEK, DisCURSIVE DEMOCRACY (1990). Although this approach owes much to Jürgen Habermas, I think it can avoid his unhelpful separation between the "lifeworld" and that of technical and instrumental rationality, as well as the need to establish ideal, uncoerced communicative contexts. The social structures of power, including communication, should be seen in a more dialectical way, and the changes in the structure of the public sphere open up possibilities-many of which Habermas himself recognizes - for reconstituting a more effective democracy. This, in turn, can counteract inequalities of power.

43. See Democracy AND DifFEREnCE: Contesting the Boundaries of THE Political (Seyla Benhabib ed., 1996).

44. See Bernard Manin, The Metamorphoses of Representative Government, 23 ECON. \& SoC'Y 133, 160 (1994).

45. $I d$. 
ism). This analysis again indicates the importance of ensuring that government takes place within a broader framework of debate and decisionmaking that is open to the active involvement of issue groups and concerned citizens. In the final section of this paper, I suggest in outline the basic principles for constituting the public sphere in the spirit of active, deliberative, democratic participation, combined with some practical suggestions indicating their particular relevance to globalization.

\section{$\mathrm{V}$}

\section{Four CONSTITUTIVE PRINCIPLES FOR DEMOCRATIZING GLOBALISM}

New forms of active citizenship and political action have been developing, often around the local and national impact of regional or global policies. The recognition that the public sphere has become fragmented into multiple intersecting networks and overlapping jurisdictional spheres emphasizes the importance of building democratic participation through new political principles, institutions, and practices. These emerging institutions should recognise the diversity of political sites in which public policies are developed and implemented through processes of interaction between these sites.

Such principles must attempt to transcend the two main traditional constitutional models, which are increasingly proving inadequate for the contemporary phase of globalization. On the one hand, liberal conceptions, based on a view of society as composed of individuals pursuing their own self-interest, see the role of the polity as complementing the market and as aiming to identify the optimal collective interest-either by authoritarian means $\left(\right.$ Hobbes $\left.^{46}\right)$ or via majoritarian representative democracy $\left(\right.$ Locke $\left.^{47}\right)$. Post-industrial capitalism, with its integrated global production and marketing networks, raises a wide range of social, environmental, and moral issues that cannot adequately be resolved by aggregating private interests, using either authoritarian or democratic methods. The alternative model of civic republicanism, on the other hand, rejects the narrow view of citizenship based on weighing and balancing competing individual interests. Its stress on an ethical politics based on visions of the common good, however, implies a communitarianism requiring shared values. In today's culturally fractured world, this takes reactionary forms and may generate conflict rather than consensus.

As Jürgen Habermas has suggested, whereas both these views tend to see the state as the center, deliberative politics can be adapted to a decentered society:

This concept of democracy no longer needs to operate with the notion of a social whole centered in the state and imagined as a goal-oriented subject writ large. Just as little does it represent the whole in a system of constitutional norms mechanically

46. See generally ThOMAs HobBes, LeViathan (Alexander Lindsay ed., Dutton 1950) (1651).

47. See generally JoHn Locke, SECOND TREATISE OF GOVERnMENT (Thomas Peardon ed., Liberal Arts Press 1952) (1690). 
regulating the interplay of powers and interests in accordance with the market model. $^{48}$

Others also have stressed the attractiveness of a direct, deliberative form of participatory democracy for solving problems in ways unavailable to representative systems:

Collective decisions are made through public deliberation in arenas open to citizens who use public services, or who are otherwise regulated by public decisions. But in deciding, those citizens must examine their own choices in the light of the relevant deliberations and experiences of others facing similar problems in comparable jurisdictions or subdivisions of government.

According to this perspective, decisionmaking, especially by public bodies, should result as far as possible from active democratic participation based on discursive or deliberative, rather than instrumental, reasoning. Instead of the pursuit of individual interests based on the assumption of fixed preferences, the aim is to go beyond an objectivist rationality (in which choices are considered to be made by reference to absolute and objective standards), without falling into the trap of relativism. ${ }^{50}$ Thus, while accepting that there is no single objective standard of truth, because perspectives are always subjective (and hence epistemology is to that extent relativist), truth can be said to be an emergent property of the deliberative interaction between perspectives (and hence its ontology is objective).

Deliberative democracy accepts the existence of a diversity of perspectives and aims to facilitate interactive deliberation about values through which pref-

\footnotetext{
48. Jurgen Habermas, Three Normative Models of Democracy, in DEMOCRACY AND DIFFERENCE, supra note 43 , at 27 . Habermas nevertheless argues that his own concept of a "politically socialising communicative context" can be translated from the nation-state to the European sphere, which entails building "a European-wide, integrated public sphere ... in the ambit of a common political culture." Jurgen Habermas, Remarks on Dieter Grimm's "Does Europe Need a Constitution?,” 1 EUR. L.J. 303, 306 (1995). Others have put forward neo-republican models for a "multi-level” European citizenship. See Richard Bellamy \& Alex Warleigh, From an Ethics of Integration to an Ethics of Participation: Citizenship and the Future of the European Union, 27 MILLENNIUM 447 (1998) (implying that the republican version of participatory democracy can be translated to the European level (although this is contested by Habermas)). It seems important, however, to accept that even Europe, which has a strong institutional base and some elements of a common political culture, does not form an integrated political unit, and hence that democratic forms need significant adaptation. It is clear, for example, that the European Parliament must play a different role from that of national parliaments, and hence it must be differently organized, just as national parliaments must adapt to deal with the Europeanization of the legislative process. This is perhaps the practical political response to the debate about the "European demos." See Peter Lindseth, Democratic Legitimacy and the Administrative Character of Supranationalism: The Example of the European Community, 99 COLUM. L. REV. 628, 675 (1999).

49. Joshua Cohen \& Charles Sabel, Directly-Deliberative Polyarchy, 3 EUR. L.J. 313, 314 (1997). Oliver Gerstenberg introduces the work of Cohen and Sabel into the debate on democracy in the European Union by pointing out how this vision opens up the argument that supra-nationalism can itself be the focus of this type of radical democracy. This is because it goes beyond existing forms of constitutional democracy bounded by market-state-civil society and shows that new forms of governance based on deliberative coordination are not conventionally public or private, pointing to a new division of labour between political agencies and directly deliberative problem-solving units. See Oliver Gerstenberg, Law's Polyarchy: A Comment on Cohen and Sabel, 3 EUR. L.J. 343 (1997); see also Christian Joerges \& Jurgen Neyer, From Intergovernmental Bargaining to Deliberative Political Processes: The Constitutionalisation of Comitology, 3 EUR. L.J. 273 (1997).
}

50. See generally DRYZEK, supra note 42. 
erences may change, or may be accommodated to each other. An emphasis on process may help to overcome the weaknesses of this model if it is conceived as a political ideal or as relying on the generation of consensus purely through the public use of reason. Crucially, account must also be taken of inequalities of power, which generate conflicting interests, as well as imbalances in the capacity to participate in a politics based on reasoning.

To this end, constitutional principles should aim as far as possible to protect the public sphere from the instrumental pursuit of private interests. Clearly, subjectivity resulting from each person's experiences, background, and aspirations is inevitable, but this should be reflexively acknowledged so that individuals and groups maintain openness to the arguments of others. Above all, public arenas should be insulated from undue influence from private interests, and debate should be conducted in terms of explicitly articulated values and aims. This objective is fundamental to the four general principles that I would put forward as constitutive of a direct-democratic, deliberative public sphere: transparency, accountability, responsibility, and empowerment. I will briefly discuss each of these in turn, although in practice, they are interdependent.

\section{A. Transparency}

Economic liberalization and globalization have led to the increasing articulation of the requirement of transparency, but until recently it generally has been directed at national governments, aiming to reduce bureaucratic obstacles to market transactions. Thus, many provisions in the WTO agreements require transparency of national regulatory and administrative procedures. This is because it is believed that regulatory measures, policies, and proposals adopted by one state may, in the context of increased global economic integration, act as obstacles to market access by firms in other states. Thus, the WTO agreements include obligations not only for accessible publication of national regulations, but also for the establishment of national contact points to provide information (including translations of relevant texts) and even for prior notification of proposals for non-standard regulations with an opportunity to make comments. ${ }^{51}$

51. Notably, Article 7 and Annex B of the Agreement on the Application of Sanitary and Phytosanitary Measures requires states to notify each other in advance of any proposals for regulations that are not based on an international standard, to "allow reasonable time for other Members to make comments in writing, discuss these comments upon request, and take the comments and the results of the discussions into account"; developed countries must provide translations of documents in English, French or Spanish. See Agreement on the Application of Sanitary and Phytosanitary Measures, Marrakesh Agreement Establishing the World Trade Organization, Dec. 15, 1993, 33 I.L.M. 1 (1994) ["WTO Agreement"], art. 7, annex B, FinAl ACT-Results of THE URuguAy Round, Apr. 15, 1994, vol. 27; 33 I.L.M. 1144 (1994). The agreement on Technical Barriers to Trade, which requires states to base their technical regulations on international standards where they exist except where they would be "an ineffective or inappropriate means for the fulfillment of the legitimate objectives pursued," focuses on transparency of conformity assessment procedures (article 10), including the requirement for inquiry points which can provide documents at reasonable cost (and for developed countries, in English, French, or Spanish). See Agreement on Technical Barriers to Trade, Apr. 15, 1994, WTO Agreement, supra, Annex 1A, FINAL ACT, supra, vol. 31; 33 I.L.M. 1125 (1994). The TRIPS agreement (article 63) also includes obligations to publish and notify laws, regulations, final judicial rulings, and administrative rulings of general application. See Agreement on Trade-Related Aspects of 
However, there are virtually no formal provisions regarding transparency of international bodies and arenas. Indeed, intergovernmental negotiations and activities are especially opaque, and both politicians and officials generally stress the importance of confidentiality in this realm, which is often excluded from national freedom of information requirements. In the European Union, it was only as a result of the legitimacy crisis, recognized in the negotiation of the Maastricht treaty, that E.U. institutions began to adopt principles of transparency. ${ }^{52}$ This was finally formally recognized in the Treaty of Amsterdam signed in June 1997. Additionally, Article 255 of the consolidated Treaty establishing the European Community now gives any E.U. citizen or resident a right of access to documents of the Council, Commission, and Parliament, subject to "[g]eneral principles and limits on grounds of public or private interest," to be drawn up by the Council. ${ }^{53}$

This provision is exceptional, perhaps even unique, in an international treaty, but should be regarded as a constitutive principle for all international bodies, and indeed any serious international regulatory activity. Nevertheless, such a principle will inevitably remain ineffective if subject to broad exceptions and if the general rules and individual decisions on what can be revealed are left to each body to decide for itself. ${ }^{54}$ Effectiveness could perhaps be improved by the establishment of Ombudsmen, as has also been done in the European Un-

Intellectual Property Protection, Apr. 15, 1994, WTO Agreement, supra, Annex 1C, FINAL ACT, supra, vol. 31; 33 I.L.M. 1 (1994).

52. See Treaty ESTABlishing the European Community, Feb. 7, 1992, O.J. (C 224) 1 (1992), [1992] 1 C.M.L.R. 573 (1992) [hereinafter EC TREATY] Declaration No. 17 (stating that "transparency of the decisionmaking process strengthens the democratic nature of the institutions and the public's confidence in the administration," and recommending that the Commission submit a report to the Council by 1993 on measures to improve public access to information). This resulted in the approval by the Council and Commission on December 6, 1993, of a Code of Conduct, which stated the general principle that "the public will have the widest possible access to documents held by the Commission and the Council," but which also required the institutions to refuse access to any document whose disclosure would undermine "the protection of the public interest (public security, international relations, monetary stability, court proceedings and investigations)" and permitted them to refuse access "in order to protect the institution's interest in the confidentiality of its proceedings." 1993 O.J. (L 340) 41. Journalists, Members of the European Parliament, and activists have waged several battles to try to ensure that these exclusions are interpreted strictly, with some support from the European Court of Justice. See generally TONY BUNYAN, SECRECY, DEMOCRACY AND THE THIRD PILlAR (1999); see also Case T-14/98, Hautala v. Council, [1999] 3 C.M.L.R. 528 (Ct. First Instance 1999). Typically, this case concerned the Council's refusal to supply a report on the criteria for arms exports, on the ground that disclosure could be harmful to the European Union's relations with third countries, and although the Court annulled the decision, it did so only because the Council had not considered whether the report could be published with sensitive parts removed.

53. TREATY OF AMSTERDAM AMENDING THE TrEATy ON EURopeAN Union Treaty ESTABLISHING THE EUROPEAN COMMUNITY, Oct. 2, 1997, O.J. (C 340) 16 (1997) [hereinafter TREATY OF AMSTERDAM].

54. Thus, the initial proposals emerging from discussions of officials of E.U. institutions for implementation of TREATY OF AMSTERDAM, supra note 53, art. 255, apparently suggested that only documents concerning legislative measures would be regarded as "accessible," while internal "working documents" would be "non-accessible," and even the former might be embargoed until after the formal adoption of the decision. See 9 STATEWATCH (1999). Such a proposal is hardly likely to gain approval, but that it was made at all is revealing of the official perspective. 
ion, ${ }^{55}$ to monitor the transparency of international bodies, and to investigate or adjudicate claims of confidentiality. The principle of transparency is just as important for apparently technical bodies, as has been pointed out by Willem Buiter in a trenchant critique of the traditionalist approach adopted by the European Central Bank, which he describes as "typical of a central banking tradition that was, until very recently, dominant across the world, which views central banking as a sacred, quasi-mystical vocation, a cult whose priests perform the holy sacraments far from the prying eyes of the non-initiates."

Transparency has now been facilitated greatly by the opportunities opened up by the Internet. Indeed, some international bodies have begun to make extensive use of this medium to make their documentation available. It is obviously very advantageous for an organization such as the WTO to be able to give such instant online access to its large and growing documents archive to all those in its 132 member countries who require it. The Internet also offers possibilities for much more interactive consultation of relevant communities by the public, and some organizations are beginning to make use of this. In practice, however, there are very great inequalities in the capacity to access the Internet, ${ }^{57}$ so that to realize the opportunities it offers also requires active programs to broaden effective participation by all affected and concerned citizens.

Finally, perhaps the key requirement is to develop and sustain information media that can help to provide the kind of forum that active public participation in deliberative debate requires. Universal public distrust of politicians, equaled only by its cynicism about journalists, is a serious indictment of our political systems. There are certainly some media organizations in some countries, as well as many able and committed individuals, dedicated to providing a rich context of information and to facilitating debate. However, the media overall, in some countries more than others, are subservient to government agendas and commercial imperatives ${ }^{58}$ and hence tend to reflect received or elite opinion. Accordingly, a key requirement for transparency in the public sphere is to ensure guarantees of media independence from both government and private dominance. News media, in particular, should be owned neither by governments nor tycoons, but by journalist collectives or trustees.

55. Carsten Grunbeck-Jensen provides an interesting evaluation from a Scandinavian perspective, particularly apposite since these countries have been influential in the moves toward transparency in the European Union, but he points out that the E.U. Ombudsman has no real teeth, having no better access to documents than the citizen. See generally Carsten Grunbeck-Jensen, The Scandinavian Tradition of Open Government and the European Union: Problems of Compatibility?, 5 J. EUR. PUB. POL'Y 185 (1998).

56. Willem H. Buiter, Alice in Euroland, 37 J. COMMON MKT. STUd. 181, 198 (1999).

57. See Saskia Sassen, Digital Networks and Power, in SPACES OF CUlTurE 49 (Mike Featherstone \& Scott Lash eds., 1999); see also Access to the Network Society: Who is in the Loop and on the Map?, U.N. DEVELOPMENT PROGRAMME, U.N. HUMAN DEVELOPMENT REPORT 61-66 (1999).

58. See Symposium, The Power of the Media in the Global System, 47 J. INT'L AFF. 1 (1993). 


\section{B. Accountability}

The past few years have seen increasing concern and debate about the accountability of all kinds of participants in public policy debates. Even in countries with apparently well-established systems of representative democracy, politicians have been subjected to new scrutiny over their acceptance of bribes, political donations, or campaign financing, as well as debates about the relationship of their personal lives and morality to their public functions. That such issues have been very widespread, not confined to countries undergoing identifiable political transitions (such as Italy, with its "tangentopoli" scandals linked to the collapse of the Christian Democracy-Communist duopoly), shows that they are symptomatic of generalized changes in the role of elected politicians, indicated in Bernard Manin's analysis of the changing nature of representative democracy. ${ }^{59}$

The increased diversity and complexity of policy issues, and the decline of mass-party politics, places new responsibilities on politicians to develop specialist expertise and resources and to manage their information sources scrupulously. They themselves are also increasingly concerned with their responsiveness to public opinion, whether expressed in their mail (and e-mails), opinion polls, or focus groups. However, the increased importance of personal charisma or name recognition for the standing of politicians, as opposed to policy or principles, has undermined their legitimacy as political representatives.

For a variety of reasons, it has become increasingly plain that democratic accountability of public bodies cannot rest only on their accountability via parliaments and elected politicians. Indeed, some kinds of decisions (such as control over interest rates) have been transferred out of the political domain to protect them from short-run electoral considerations. An increasingly wide range of matters has been delegated to specialist bodies operating under defined mandates, with powers of either recommendation or actual decision. Where there is a governmental input, it is generally made by non-elected officials who are subject to only superficial supervision by a succession of partiallybriefed elected politicians. Often, issues are not resolved by a decision from one particular body but are subject to interacting decisionmaking powers of various bodies at the national level, and even more so at the global level.

Thus, for example, the development and use of biotechnology depends on decisions by patent offices, scientific and ethical committees, food and drug regulators, national governments, and perhaps ultimately WTO disputesettlement procedures. It is important not only that all such public bodies operate under explicit and specific accountability mandates, but also that their decisions are taken in a context of well-informed debate involving as broad a range of the public as possible. The channels of accountability are now less vertical, leading into central government, and more horizontal, entailing interaction between various local, national, regional, and international public arenas.

59. See supra text accompanying notes $44-45$. 
Thus, while elected politicians certainly should play an important, and perhaps determinative part, ensuring accountability within the public sphere entails the involvement of a wide range of entities and groups, all of which have their own constituencies and accountability mechanisms. This is perhaps the reason for the increased use in recent years of the somewhat amorphous term "civil society." The point here is that there is no single accountability mechanism to the broad public. Participants in public debate can make different contributions, but it is incumbent on each of them to clarify to whom and how they are accountable. Indeed, there have been increasing pressures for all kinds of organizations to improve their accountability, not only to their direct members, but to a wider constituency of stakeholders.

Corporations have also come under pressure to be responsive to the needs and demands of their customers, suppliers, workers, and contractors, as well as local communities and the wider society, with respect to some of their activities. Their traditional focus on the bottom line of direct costs and revenues to generate shareholder value has now been overtaken by the need for a more continuous two-way dialogue with this wider constituency and concern for the "triple" bottom line and long-term values, such as reputation. Many business managers need to be convinced that this entails more than just improved communication of decisions made in their boardrooms. It is no coincidence, however, that the lead is being taken by companies that have been hit by unexpected public reactions to policies that they believed had the legitimacy of approval by all relevant regulatory bodies. This has been shown, for example, by Shell's experiences over the Brent Spar oil platform disposal and the impact of its oilfields on local communities in eastern Nigeria ${ }^{60}$ as well as the experiences of biotechnology companies in relation to genetically modified organisms. ${ }^{61}$ The damage to investor confidence in the biotechnology sector should bring home to all concerned the importance of improving public confidence in regulatory decisions.

In reply, many have challenged the various campaigning organizations and NGOs to justify their claims that they represent public opinion. Such organizations cover a wide gamut and clearly do have a responsibility to clarify for whom they speak, as well as to maintain an active dialogue with their members and stakeholders. They also are vulnerable to bottom-line pressures from their sources of funding, which may lead them to adopt high-profile campaigns or maintain positions for their attractiveness to the media rather than their intrinsic validity. There may be differences of perspective between different elements of their constituencies, such as a divergence of belief between subscribers and contributors in developed countries and those in less developed countries who are the intended beneficiaries of development organizations. Interestgroup institutions, such as business and trade associations and trade union organizations, in principle represent their members and can claim accountability

60. See Nick Mayhew, Trouble with the Triple Bottom Line, Fin. TimEs, Aug. 10, 1998, at 10.

61. See Jane Martinson, Monsanto Pressured to Sell Off GM Assets, GuARDian, Oct. 22, 1999, at 1. 
ultimately via election certainly at the international level; however, this may be a distant link. There is much they could do to improve the active involvement of their grass-roots memberships.

In summary, the roles of various kinds of participants should be defined according to the contribution they can make to public debate based on generally applicable values. Procedures for consultation and involvement in decisionmaking should reflect their particular roles, as well as accommodating and safeguarding against possible distortions resulting from advancement of private interests.

\section{Responsibility}

Participants in public deliberation may also be said to have obligations of responsibility that are distinct from their accountability to their particular constituencies. ${ }^{62}$ These include principles for maintaining a separation between involvement with private interests and the conduct of public duties and activities, as well as norms and practices of responsible behaviour developed by and for particular groups and professions. The acceptability and effectiveness of public policy decisions increasingly depend on the quality of the reasons supporting them, which in turn requires all those involved in debates to uphold high standards of probity. This is evidenced by the increased attention being given to ethical standards by and for a wide range of groups and professions, many of which have been formally articulated in codes or even in law.

An important aspect of this change is to define and police the line between professional or public responsibilities and obligations to a commercial client or employer. Thus, banks and financial intermediaries are now obliged to report suspicious transactions under money-laundering legislation, enacted nationally but stimulated and monitored by the international regulatory network centred on the Financial Action Task Force. ${ }^{63}$ External auditors may have specific responsibilities to report to regulatory authorities, for example to banking supervisors, if they uncover breaches of regulatory requirements. Officials or civil servants may be protected from disciplinary or even legal proceedings for breaches of confidence if they can show that they acted in the public interest. However, too often, the formal rules on these matters are not designed to encourage or protect disclosures in the public interest, but rather to protect public or private bureaucracies from undesirable obligations or revelations. The

62. This, of course, depends on who is included in that constituency. See generally JONATHAN P. Charkham, KeEPing GoOd COMPANy: A Study of CORPORATE Governance in Five COUNTRIES (1994). For example, it is argued that potential conflicts between corporations' duties to their shareholders and to their stakeholders should be avoided by limiting their accountability to shareholders, while accepting that they have broader social responsibilities. See id. I prefer here to use the term responsibility in relation to how debate should be conducted.

63. This is a typical informal global regulatory body, set up by a decision of the Group of Seven, but located at the Organisation for Economic Development ("OECD") in Paris. See Financial Action Task Force on Money Laundering (visited Oct. 4, 2000) <http://www.oecd.org/fatf>. 
strengthening of these bureaucracies should be regarded as a significant contribution toward the democratization of global governance.

More broadly, all those involved as information gatekeepers or knowledge producers, now more than ever, need to operate reflexively, with an awareness of what impact their professional or scientific practices and contributions have on the quality of public debate. These matters are not uncontroversial, as can be seen in the debates about the criteria applied in peer-review for publication of studies on controversial technologies, such as genetically-modified organisms, or whether there should be an obligation to publish results from all pharmaceutical drug evaluations.

\section{Empowerment}

My final principle should be regarded as an overriding one, because without it, the other proposals for strengthening the public sphere as a deliberative arena would do little more than provide an alibi for the maintenance and extension of the system of elite decisionmaking. It is all too easy for those with decisionmaking power to pay lip-service to the need for public consultation or participation, although one can still be surprised at the frequency with which they neglect even this bare minimum. It is often only as a result of a policy setback, such as the breakdown of the MAI negotiations, that those in power resort to a "charm offensive" to try to win support from potential critics. Frequently, also, they prefer to distinguish carefully between procedures for consultation with public interest or activist groups and their discussions with business or corporate interests. This inevitably raises suspicions that decisionmakers are more open to influence from private interest groups, and that they regard consultation with public interest-groups and concerned citizens (or even legislators) as an irritating time-waster, perhaps necessary to forestall subsequent criticism. It is all too rare to find an acknowledgement that the quality of public decisions can be improved if they take place in a context of full participation by all concerned and affected groups.

The challenge, therefore, is to find ways to ensure effective participation in debate and decisionmaking, especially of disadvantaged citizens and groups. Much of the political opposition to, and disaffection with, globalization and liberalization results from the unleashing of forces that exacerbate inequalities within and between states often portrayed as a battle between the global market and the national state. This view tends to neglect the ways in which the transformation of the world market is being brought about by complex processes of international re-regulation. A key example is the restructuring of global telecommunications, in which giant firms battle for market shares, entailing struggles over technical standards, sectoral regulation (notably governing interconnection rights and charges), and competition rules through interactions between a variety of national and international bodies. A key issue, which has for several years been preoccupying the International Telecommunications Union ("ITU"), is the system of settlements with respect to international calls, which 
entails revenue-sharing resulting in transfers, mainly from developed to developing countries, estimated at seven to ten billion dollars per year. ${ }^{64}$ There is considerable pressure to reform this system in order to end discrimination in charges between international and national calls, consistent with the liberalization of telecommunications services negotiated bilaterally, regionally (especially in the European Union), and through the WTO. Yet it is also widely recognized that a truly global telecommunications system is unattainable unless equivalent (or better) means are found to finance the expansion and upgrading of telecommunications networks in developing countries. ${ }^{65}$

Global battles over regulation also concern revenue distribution and redistribution, not just "neutral" rules that allow markets to operate "freely." Many other debates and battles over international regulatory arrangements also have (re)distributional consequences or implications, running often to many millions or billions of dollars, such as competition laws and policies, environmental protection schemes, intellectual property rights, food safety requirements, agricultural support and rural development measures, prudential rules for financial institutions, and international tax arrangements. Too often, the talk of "market friendly" regulation implies rules that favor the economically powerful, whereas balanced and sustainable long-term economic growth may require measures to protect, encourage, and stimulate less developed or disadvantaged groups, regions, and countries. For example, the international patent system ensures that billions of dollars are channeled into research and development for new pharmaceutical drugs. Inevitably, however, the vast bulk of this is aimed at combating health problems of the affluent. ${ }^{66}$ It has proved extremely difficult for the World Health Organization to negotiate collaborative arrangements for the development of new drugs to combat tropical diseases such as malaria, which would be of immense benefit on a global level $;{ }^{67}$ yet drug companies would fiercely resist the proposal made by Médecins sans Frontières to fund such initiatives through a tax on drug sales.

An important function of direct democracy is to open up the received wisdom of closed bureaucratic or technocratic decisionmakers to critical and destabilizing ideas. Perhaps this cannot be institutionalized without blunting the

64. See Dr. Henry Chasia, Opening Remarks to the Annual Council of the Commonwealth Telecommunication Organization (Sept. 29, 1998). These remarks and other documentation on the issue are available in the special area of the ITU website. See International Telecommunication Union (visited Oct. 9, 2000) <http://www.itu.int/itudoc/osg/colloq/chai_rep/sevencol/sevencol.html $>$.

65. See the comprehensive report by Michael Tyler, Transforming Economic Relationships in International Telecommunications (1997) for ITU Regulatory Colloquium No. 7, on The Changing Role of Government in an Era of Telecommunications Deregulation (visited Sept. 23, 2000) <http://www.itu. int/itudoc/osg/colloq/chai_rep/sevencol/sevencol.html>.

66. Research done for Médecins sans Frontières shows that of 1233 drugs licensed worldwide between 1975 and 1997, only 13 were for tropical diseases, of which two were slight modifications of existing drugs, two developed for the U.S. military, and five were the outcome of veterinary research. See Bernard Pecoul et al., Access to Essential Drugs in Poor Countries-A Lost Battle?, 281 J. AM. MED. Ass'N 361; see also David Pilling, In Sickness and in Wealth, FIN. TIMES, Oct. 22, 1999, at 23. html $>$.

67. See The Multilateral Initiative on Malaria (visited Oct. 9, 2000) <http://www.malaria.org/MIM. 
critical edge of political protest, although sometimes well-considered and substantiated arguments take second place to spectacular actions designed to attract media attention. Responsive and confident political systems can find ways to make themselves more open to external critical input. For example, public forums or commissions could be empowered to conduct inquisitions into policies or issues or specific decisions could be delegated to citizen juries, based on systematic presentation and examination of evidence.

VI

\section{CONCLUSION}

It is difficult not to close an article of this kind without some stirring rhetoric about the importance of this matter for the future of the planet in the new millennium. Major issues are certainly at stake, but their scope and complexity are hard to grasp in full. Globalization seems to produce scandals, panics, and crashes, which we can hope will remain episodic events. However, not only systemic stability is at stake in the construction of global governance, but also our ability to establish the conditions for economic activity that will finally respond to the needs of the world's poor and dispossessed for dignity and social justice. 